\title{
UMBRAGEOCORIS KONDOROSYI: A NEW GENUS AND SPECIES OF BIG-EYED BUGS FROM NEW GUINEA (HETEROPTERA: LYGAEOIDEA: GEOCORIDAE)
}

\begin{abstract}
PÉTER KóBor
Department of Zoology, Hungarian Natural History Museum, H-1088 Budapest, Baross u. 13, Hungary; E-mail: kobor.peter@nhmus.hu; https://orcid.org/0000-0003-0266-7303 Department of Zoology, Plant Protection Institute, Centre for Agricultural Research, Hungarian Academy of Sciences, H-1022 Budapest, Hermann Ottó u. 15, Hungary
\end{abstract}

Umbrageocoris gen. $\mathrm{n}$. and its types species Umbrageocoris kondorosyi sp. n. (Hemiptera: Heteroptera: Lygaeoidea: Geocoridae) is now described from New Guinea. The placement of the genus within the subfamily Geocorinae is discussed.

Keywords: New Guinea, Geocorinae, new genus, new species, key, distribution, taxonomy.

\section{INTRODUCTION}

The subfamily Geocorinae is a moderately species rich taxon of Lygaeoidea (sensu Henry 1997), comprising about 15 genera and 147 species (HenRY \& Dellapé 2009). Members of this group are among the most important lygaeoids because of their agricultural significance as predators of thrips and aphids (Kumar \& ANANTHAKRishnan 1985, SweEt 2000). Although a thorough revision of the fauna occurring in China is available (Zheng \& Zou 1981), the Oriental fauna is poorly studied, and most available contributions are highly outdated (e.g. Uhler 1860, Distant 1918). Contrastingly, the species occurring in Australia have been thoroughly revised (Malipatil 1994, Malipatil 2012, Malipatil \& Blackett 2013). The geocorines of the Papuan Subregion (sensu UDVARDY 1975) are virtually unknown; only four species have been reported from the archipelago: Geocoris willeyi Kirkaldy, 1905; Germalus bipunctatus (Montandon, 1907); Geocoris leopoldi Schouteden, 1933 and Germalus fuscovittatus Malipatil, 2013; latter is distributed in northern part of Queensland and islands of the Torres Strait as well (Malipatil \& Blackett 2013).

János Balogh (1913-2002), Hungarian acarologist and soil zoologist, made multiple collecting and research trips to New Guinea (MaIN 1982) and deposited a vast unidentified material of ground-dwelling arthropods - the majority was collected by sifting leaf litter - in the collections of Hungarian Natural History Museum. In the course of the study of Balogh's specimens a new genus and species of Geocorinae was found. The description of the new taxon and the discussion of its placement within the subfamily are the subject of present paper. 


\section{MATERIAL AND METHODS}

Abbreviation of depositories: HNHM - Hungarian Natural History Museum, Budapest; BMNH - Natural History Museum, London; BPBM - Bernice P. Bishop Museum, Honolulu; Label data cited verbatim. Lines on labels are separated by "/", different labels are separated by "//".

External and genital structures were studied and imaged with Keyence VHX 5000 digital microscope. Hand drawings were made by the author. Genitalia were prepared for examination with detaching the whole abdomen and soaking it overnight in lactic acid solution at room temperature. When soaking in lactic acid, structures remain more flexible than by $\mathrm{KOH}$ maceration according to author's experiences. This method also prevents "over-clearing" of structures (BLAHNIK et al. 2007), thus additional dye staining is not necessary before further dissection, observation or photographic documentation. Measurements were made both with the use of calibrated ocular micrometer or on scaled photographs using ImageJ software; values are given in millimetre.

Due to the lack of availability of ethanol preserved specimens suitable for DNAextraction, no molecular phylogenies were performed and relationships of new taxon were discussed on morphological basis. The author supports the opinion of PÁLL-GERGELY (2017) that clear, well-established conclusions and hypotheses based on thorough morphological study can offset the lack of molecular data.

\section{RESULTS}

\section{Key to genera of New Guinean Geocorinae}

1. Head pentagonal, eyestalks somewhat erect; ocular sulcus complete, welldefined. Anterior margin of pronotum almost straight; pronotal disc with deep punctation; pronotal callosities well-developed, slightly bulging. Scutellum subequilateral, median trifurcate carina distinct, slightly bulging. Margins of clavus parallel, claval commissure developed. Peritreme of metathoracic scent gland as in Fig. 4A. Germalus Stål, 1862 (2 species)

- Head pentagonal or lunate, eyestalks not erect, ocular sulcus reduced or if complete, less conspicuous. Anterior margin of pronotum curved; pronotal disc with fine punctation; pronotal callosities somewhat reduced. Scutellum elongate; apical part of median trifurcate carina at least partly reduced. Peritreme of metathoracic scent gland as in Fig. 4B, C.

2. Head pentagonal; ocular sulcus slightly visible, but complete. Labial trough Y-shaped with suture extending to base of head. Basal width of pronotum subequal to length. Apical part of scutellar trifurcate carina partly reduced, but visible. Corium only punctate along veins. Metathoracic scent gland as in Fig. 4B.

Umbrageocoris gen. $n$. 
- Head lunate, broadened; ocular sulcus reduced completely. Labial trough closed, suture absent. Basal width of pronotum about $2 \times$ of length. Trifurcate carina of scutellum only basally present. Corium with irregular punctation in intervanals. Peritreme of metathoracic scent gland as in Fig. 4C.

Geocoris Fallén, 1814 ( 2 species)

\section{Umbrageocoris gen. $n$.}

(Figs1-4)

Type species: Umbrageocoris kondorosyi sp. n.

Description - Body elongate oval; integument shiny, lacking conspicuous pubescence (Fig. 1A). Head pentagonal; surface smooth, shiny; vertex with a thin longitudinal furrow extending from between the ocelli to middle of clypeus. Eyes big, reniform, moderately stylate; ocular sulcus slightly visible but complete (Fig. 2B). Proportion of antennal segments: segment I shortest, segment II longest, segments III and IV subequal in length. Margins of jugae somewhat projecting, forming a U-shaped rim; labial trough closes at midline of head, suture formed by margins extending to base of head. Labial segment I not reaching base of head, segment II shortest, segment III subequal to I, segment IV longest, apex reaching about the line of metacoxae. Thorax. Pronotum trapezoidal with anterior margin and edges broadly convex. Surface shiny with coarse, dense punctation except anterior and posterior margins, callosities and humeral angles. Margins, callosities and humeral angles slightly elevated. Anterior half of lateral margins of pronotum slightly carinate and impressed behind callosities. Scutellum almost equilateral, sharply pointed apically, surface with dense punctuation except trifurcate median carina. Apical part of carina expressed, elevated, basal parts reduced but visible. Hemelytron macropterous with well-developed membrane, length of membrane subequal to length of corium. Margins of clavus converging to apex; claval commissure reduced, inconspicuous. Costal margin suddenly widening at third of length; costal region widest at about half of length. Thoracic pleurites and sternites with dense, strong punctation except supracoxal lobes, peritreme of metathoracic scent gland and dorsal edge of metapleurite (Fig. 2A). Peritreme of metathoracic scent gland situated ventro-laterally, near anterior margin of metathorax; shape ear-like, dorsal rim slightly curved downwards. Evaporative area small, narrow, not reaching dorsal margin of supracoxal lobes (Figs 2B, 4B). Abdomen shiny, with sparse fine pubescence. Abdominal tergites III-V with surface strongly wrinkled (Fig. 2D). Trichobotria on connexiva V-VI conspicuously bulging (Fig. 2C). Abdominal venter finely rugous. Genitalia: Male pygophore with conspicuous lateral processes on dorsal half of the opening; paramere (Fig. 3) with blade elongate, somewhat curved, lacking conspicuous setae or pubescence; gonoporal process with 10 coils.

Etymology - The name of the is composed of the Latin noun umbra (= shade, night, darkness), referring to the dorsum being dark brownish laterally margined with ochraceous, endowing it with a "shaded look", and Geocoris, a closely related genus. Gender masculine.

Diagnosis - Umbrageocoris gen. $\mathrm{n}$. can be separated from other geocorines of the region with combination of following characters: labial through 
Y-shaped with suture reaching base of head; labial segment II shorter than III, segment IV longest; clavus gradually narrowing towards apex, claval commissure reduced; corium punctate along veins; peritreme and evaporatorium of metathoracic scent gland as in Fig. 4B; surface of abdominal terga III and IV rugous medially; male paramere slender, blade narrow, curved, surface lacking pubescence.

Remarks - Umbrageocoris gen. n. resembling most to the Australian genus Stylogeocoris Montandon, 1907, nevertheless there are some remarkable differences separating these genera. Based on MaLipatiL's (1994) revisionary work on Stylogeocoris and studying the holotype of Stylogeocoris biroi Montandon, 1907 (HNHM), this genus can be diagnosed with the combination of following characters: labial segment 2 and 3 subequal in length; ocular sulcus complete, distinct; margins of clavus almost parallel, claval commissure developed; abdominal terga III and IV punctate. In Umbrageocoris labial segment II is conspicuously shorter than segment III; margins of clavus gradually converging, claval commissure reduced; abdominal terga III and IV rather wrinkly than punctate. Male paramere is stouter, more curved in Stylogeocoris compared to Umbrageocoris. Furthermore, paramere of Umbrageocoris is lacking pubescence. Comparing to the Geocoris Fallén, 1814 distributed in the archipelago (Geocoris willeyi Kirkaldy, 1905 and G. leopoldi Schouteden, 1933; holotypes examined) the following differences can be observed: the new genus is more slender in general appearance than the other two species; head more pentagonal, ocular sulcus slight, but complete, not reduced; pronotal callosities more developed in Umbrageocoris; apical part of trifurcate carina of scutellum slight, but not reduced; corium of hemelytron without punctation in intervanals. In terms of Germalus, the most remarkable differences are the proportions of labial segment II-III (similarly as in the case of Stylogeocoris) and the arrangement of peritreme of metathoracic scent gland (Fig. 4A, B).

If looking at genus Geocoris in general, species similar to Umbrageocoris can be found in other biogeographical regions. Nevertheless, it has to be noted

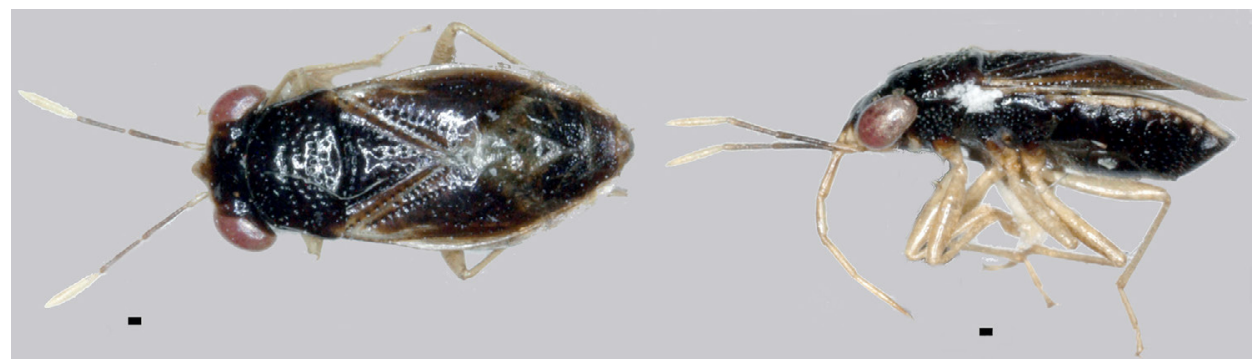

Fig. 1. Habitus of Umbrageocoris kondorosyi sp. n.: A = dorsal (holotype, HNHM), B = lateral (paratype, $\mathrm{BMNH}$ ) 

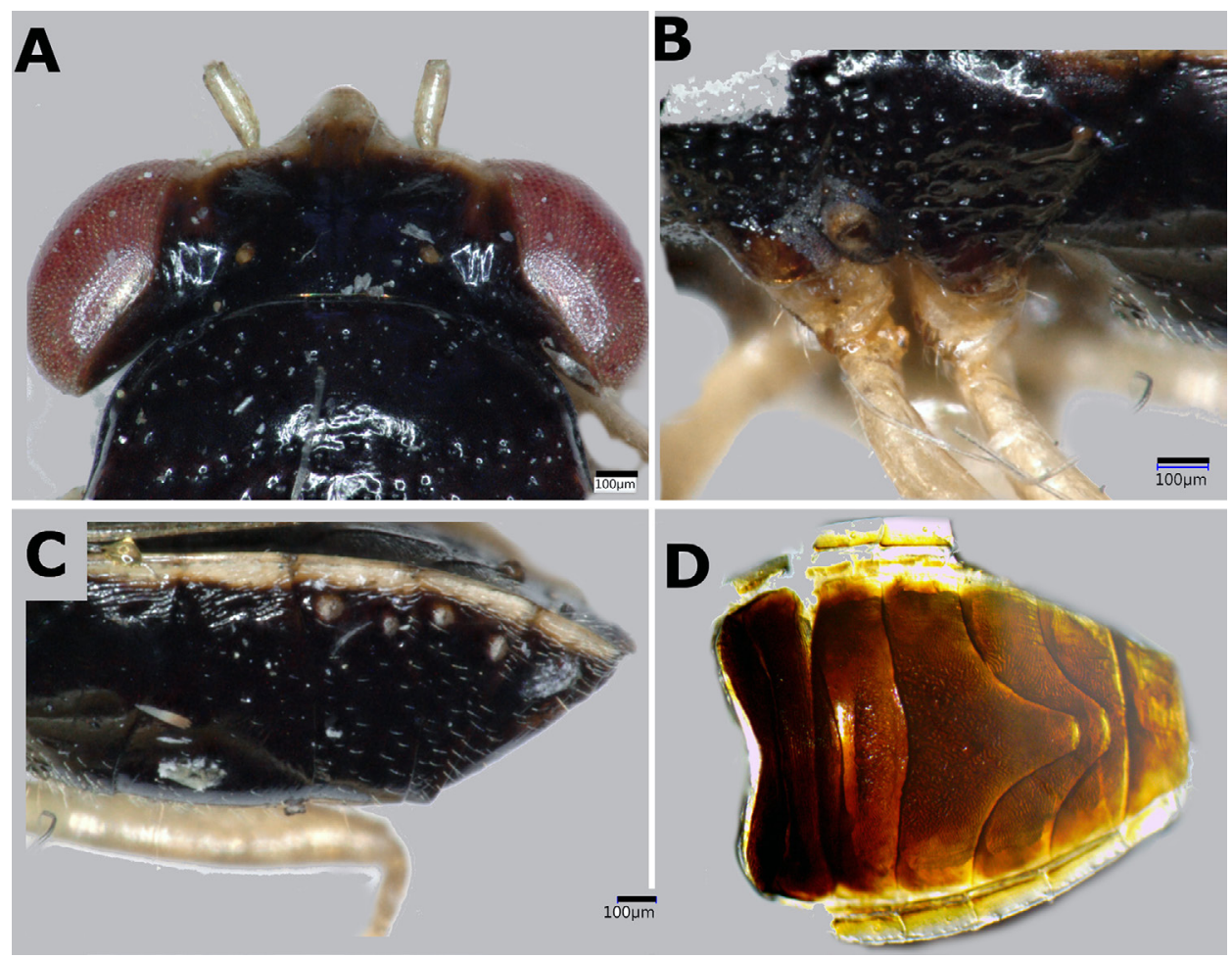

Fig. 2. Photos of Umbrageocoris kondorosyi sp. $\mathrm{n} .: \mathrm{A}=$ dorsum of head, $\mathrm{B}=$ venter of head, $\mathrm{C}=$ peritreme and evaporative area of metathoracic scent gland, $\mathrm{D}=$ dorsolateral trichobotria of abdomen

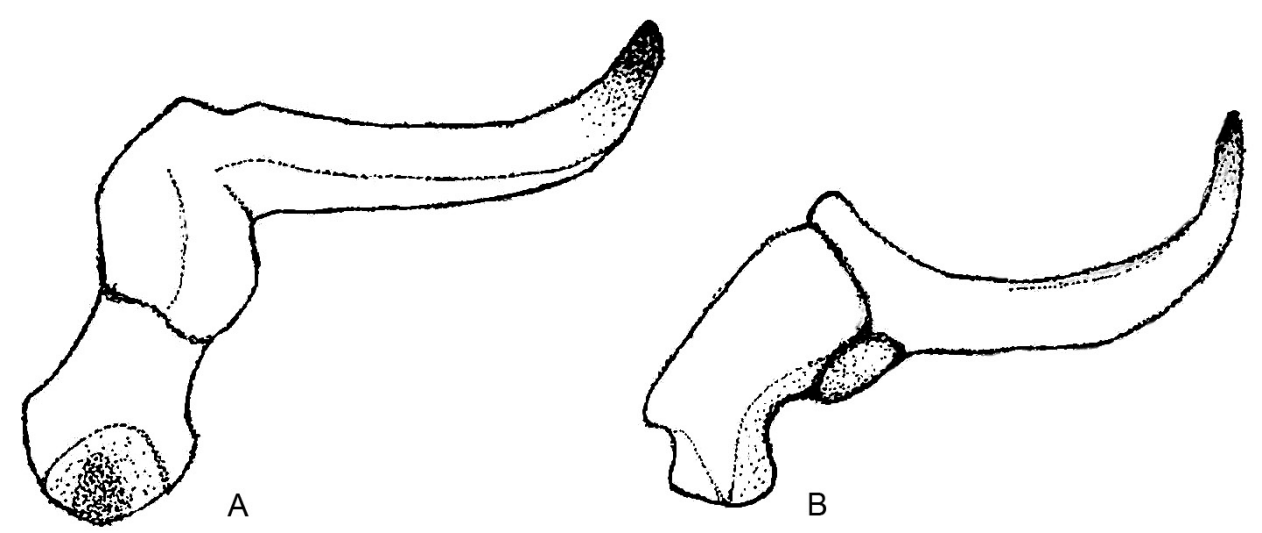

Fig. 3. Male paramere of Umbrageocoris kondorosyi sp. n. from different angles 
that more authors consider the genus Geocoris "an ill-defined group of species belonging to perhaps several distinct genera" (REAdio \& SweEt 1982, MALIPATIL 1994) which is in need of a thorough revision. Based on the literature available and own observation, the author of recent study supports this opinion and concludes that the given combination of characters is eligible to separate this taxon on generic level from other members of New Guinean fauna. One of the most convincing characters is the arrangement and shape of the outer structures of metathoracic scent efferent apparatus (Fig. 4), which is showing remarkable differences if compared to Geocoris and Germalus species of the region. Based on the results of recent study and unpublished findings of the author this character might have significant value in taxonomy and phylogeny of Geocoridae. Similar findings were concluded by Kment and Vilimoví (2010) in family Tessaratomidae (Heteroptera: Pentatomoidea).

\section{Umbrageocoris kondorosyi sp. $\mathrm{n}$.}

(Figs 1-4)

Material examined - Holotype. $\widehat{\jmath}$ (HNHM): New Guinea / Loloki, $15 \mathrm{~km} \mathrm{~N}$ of / Port Moresby / 30. III. 1965. // Nr. 2. / Coll. Balogh et Szent-Iványi (both labels handwritten).

Paratypes. 1 \& (BMNH): NEW GUINEA: NE / Wau, 1200 m / I. X. 1976 (line handwritten) // on Turnip / cv. White stone / (Brassica rapa) (label handwritten) // W. C. Gagne / Collector / BISHOP // C.I.E.COLL / A. 9273 (numbers handwritten). 1 ઈ, 2 q (HNHM): NEW GUINEA Wau / Bishop Museum / Field Station // 15-25. IV. 1965. / leg. J. Balogh Szent-Iványi. 2 ô, 1 甲 (HNHM): New Guinea / Loloki, 15 km N of / Port Moresby / 30. III. 1965. // Nr. 2. / Coll. Balogh et Szent-Iványi (both labels handwritten). 1 ð (HNHM): New Giunea / 50 km NNE of / Port Moresby / 31. III. 1965. // Nr. 4. / Coll. Balogh -/ Szent-Iványi. 1 ㅇ (HNHM): New Guinea / Haus Copper Wau / Mt. Missim / 22-24. IV. 1965 // Nr. 56 / Coll. Balogh et Szent-Iványi.

Description - Colouration. Body mostly dark brownish. Head. Vertex with extended dark brownish region exceeding base of clypeus. Apical half of clypeus, mandibular plates
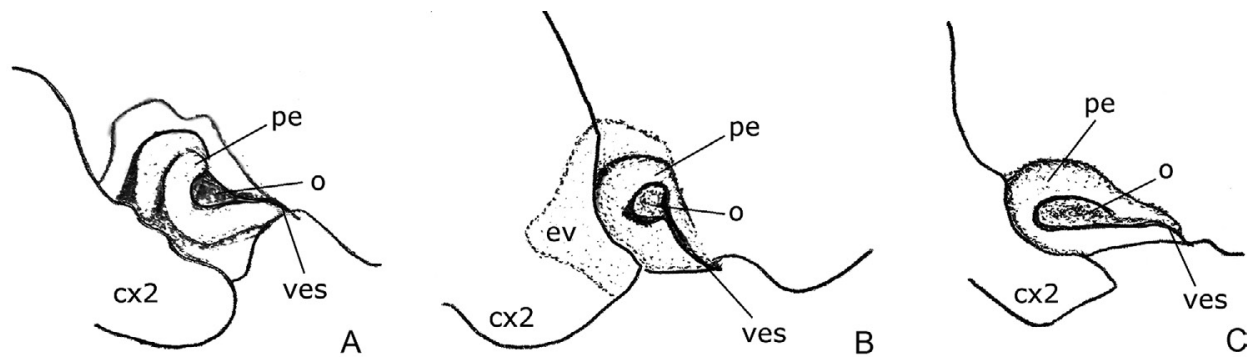

Fig. 4. Peritreme of metathoracic scent gland in New Guinean Geocorinae: $\mathrm{A}=$ Germalus Stål, 1862; $\mathrm{B}=$ Umbrageocoris gen. n.; $\mathrm{C}=$ Geocoris Fallén, 1814. Legend: $\mathrm{cx} 2=$ mesocoxa, ev = evaporatorium, $\mathrm{pe}=$ peritreme, $\mathrm{o}=$ ostiole, ves $=$ vestibular $\mathrm{scar}$ 
and antenniferous tubercles ochraceous. Eyes reddish, ocelli ochraceous. Antennal segment I ochraceous, infuscated ventrally; segment II-III fuscous, base of segment II and apex of segment III with ochraceous annulation basally; segment IV entirely ochraceous. Head ventrally ochraceous with dark fuscous "collar" at base. Labial segments ochraceous; segment I sometimes with irregular fuscous marking in basal half. Thorax. Pronotum dark brownish with small ochraceous spots of various extent at humeral angles. Scutellum uniformly dark brownish. Hemelytra semi-hyaline ochraceous with extended fuscous regions on clavus and corium. Costal margin and membrane margined with brown. Thoracic pleurites and sternites dark brownish; prothorax with ochraceous collar ventrolaterally; supracoxal lobes and orifice of metathoracic scent gland variably ochraceous or pale fuscous. Legs uniformly ochraceous. Abdomen. Abdominal segments dark brownish; connexiva marginated with ochraceous laterally; bulges of spiracles on segment V-VI ochraceous.

Structure - Body surface shiny without conspicuous pubescence. Head. Ocular sulcus slight, but complete. Width of head greater than basal width of pronotum (ratio: 1:0.92). Sparse, bristle like setae present above antenniferous tubercles. Ratio of antennal segments: 1:2.29:2:2. Antennal segments covered with sparse, decumbent setae. Ratio of labial segments: 1:0.73:0.93:1.33. Thorax. Pronotum trapezoidal; anterior edges more, posterior margins less curved. Disc of pronotum with deep, dense punctuation. Ratio of pronotum length to basal width: 1:1.55. Scutellum shiny with dense, strong punctuation except elevated, trifurcate median carina. Length and width of scutellum subequal (ratio: 1:0.96). Hemelytron macropterous with well-developed membrane. Incomplete row of punctures at corial margin of clavus. A row of punctures at corium near claval margin splits into two diverging rows at $2 / 3$ of length. Radius punctate at almost full length; strong punctuation in apical third of R-M region. Thoracic pleurites with strong, dense punctation. Abdomen. Connexiva with sparse decumbent pubescence; genital capsule with few stronger setae.

Measurements [holotype (minimum and maximum of studied specimens)] - Total body length: 3.90 (4.00-4.53) ; head length: 0.50 (0.50-0.53); head width: 1.53 (1.57-1.70); distance of ocelli: 0.47 (0.47-0.50); antennal segments: 0.20-0.51-0.46-0.46 (0.23-0.54-0.470.47 - 0.25-0.55-0.48-0.48); labial segments: 0.48-0.34-0.45-0.64 (0.50-0.36-0.56-0.67 - 0.530.40-0.58-0.70); pronotum length: 0.93 (0.93-0.97); pronotum width: 1.37 (1.47-1.53); scutellum length: 0.77 (0.83-0.87); scutellum width: 0.73 (0.87-0.90).

Distribution - Every specimen known to the author is originated from the mountain rainforests near Wau and Port Moresby, eastern New Guinea.

Etymology - The species is named as a tribute to the work of the excellent Hungarian heteropterist, Előd Kondorosy, professor at University of Pannonia.

Acknowledgements - The author would like to express his gratitude towards Mária Ronkay (HNHM) and Mick Webb (BMNH) for the borrowed material. Furthermore, to Dávid Rédei (University of Nankai) and to an anonymous reviewer for their useful comments and advises during the preparation of manuscript. 


\section{REFERENCES}

Blahnik, R. J., Holzenthal, R. W. \& Prather, A. (2007): The lactic acid method for clearing Trichopter genitalia. Pp. 9-14. In: Bueno-Soria, J., Barba-Álvarez, R. \& Armitage, B. (eds): Proceedings of the XIIth International Symposium on Trichoptera, June 18-22, 2006. - Caddis Press, Colombus.

Distant, W. L. (1918): Rhynchota VII. In: Shipley, A. E. (ed.): The fauna of British India including Ceylon and Burma. - Taylor and Francis, London, 232 pp.

Henry, T. J. \& Dellapé, P. M. (2009): A new genus and species of Oxycarenidae (Hemiptera, Heteroptera, Lygaeoidea) from Argentina. - ZooKeys 25: 49-59. https://doi. org/10.3897/zookeys.25.244

Kment, P. \& Vilimoví, J. (2010): Thoracic scent efferent system of the Tessaratomidae sensu lato (Hemiptera: Heteroptera: Pentatomoidea) with implication to the phylogeny of the family. - Zootaxa 2363: 1-59. https://doi.org/10.11646/zootaxa.2363.1.1

Kumar, N. S. \& AnANThakrishnan, T. N. (1985): Geocoris ochropterus Fabr. as a predator of some thrips. - Proceedings, Indian National Science Academy, Biological Sciences 51(2): 185-193.

MaIn, B. Y. (1982): Some zoogeographic considerations of families of spiders occurring in New Guinea. Pp. 583-602. In: Gressit, J. L. (ed.): Biogeography and ecology of New Guinea. - Springer, Dordrecht. https://doi.org/10.1007/978-94-009-8632-9_27

Malipatil, M. B. (1994): Revision of Australian Geocoris Fallen and Stylogeocoris Montandon (Heteroptera: Lygaeidae: Geocorinae). - Invertebrate Systematics 8(2): 299-327. https://doi.org/10.1071/IT9940299

Malipatil, M. B. (2012): Australocorinae, a new subfamily of Geocoridae (Hemiptera: Heteroptera: Lygaeoidea) from Australia, with descriptions of a new genus and two new species. - Zootaxa 3554: 75-88.

Malipatil, M. B. \& Blackett, M. J. (2013): Review and revision of Australian Germalus Stål, with new genera and further new species of Australian Geocorinae (Hemiptera: Heteroptera: Geocoridae). - Zootaxa 3746(2): 257-300. https://doi.org/10.11646/ zootaxa.3746.2.3

PÁll-Gergely, B. (2017): Should we describe genera without molecular phylogenies. Zootaxa 4232(4): 593-596. https://doi.org/10.11646/zootaxa.4232.4.11

Readio, J. \& SweEt, M. H. (1982): A review of the Geocorinae of the United States east of 100th meridian (Hemiptera: Lygaeidae). - Entomological Society of America Miscellaneous Publications $\mathbf{1 2} .92 \mathrm{pp}$.

Sweet, M. H. (2000): Geocoridae. Pp. 719-720. In: Schaefer, C. W. \& Panizzi, A. R. (eds): Heteroptera of economic importance. - CRC Press, Boca Raton.

Uhler, P. R. (1860): Hemiptera of the North Pacific exploring expedition under Com'rs Rogers and Ringold. - Proceedings of the Academy of Natural Sciences of Philadelphia 12: 228.

Zheng, L. Y. \& Zou, H. G. (1981): Lygaeidae. A handbook for the determination of the Chinese Hemiptera-Heteroptera 2: 1-215.

Received July 5, 2018, accepted November 21, 2018, published March 18, 2019 